DOI: https://doi.org/10.32838/2523-4803/69-4-7

удК 338.242

\title{
Горбаченко С.A.
}

кандидат економічних наук, доцент,

доцент кафедри менеджменту та інновацій,

Одеський національний університет імені I.I. Мечникова

\section{Horbachenko Stanislav}

Odessa I.I. Mechnikov National University

\section{КОНКУРЕНТОСПРОМОЖНІСТЬ МЕНЕДЖМЕНТУ МОРЕГОСПОДАРСЬКОГО КОМПЛЕКСУ УКРАЇНИ}

\begin{abstract}
У статті розглядаються теоретичні питання щодо дефініції категорії «конкурентоспроможність менеджменту». Сформульовано основні принципи конкурентоспроможного управління. В контексті визначення резервів для оптимізаиії проведено SWOT-аналіз морегосподарського комплексу України та ідентифіковано основні управлінські проблеми. Серед останніх - адміністративна неузгодженість та відсутність належного професійного рівня менеджменту. Визначено, щъо забезпечення конкурентоспроможності менеджменту вимагає від управлінського персоналу не тільки професійних навичок та досвіду, але й лідерських якостей, емоиійного інтелекту та креативних здібностей. Доведено необхідність системного підвищення менеджментом власних професійних компетениій протягом усієї кар'єри. Зроблено пропозиції щодо формування основних характеристик управліниів нового покоління, що мають забезпечити конкурентоспроможність менеджменту морегосподарського комплексу в майбутньому.
\end{abstract}

Ключові слова: морегосподарський комплекс, інновачія, конкурентоспроможність менеджменту, лідерство, креативність, емочійний інтелект.

Постановка проблеми. Розвиток морегосподарського комплексу є можливим лише у відповідному зовнішньому середовищі за умови визначення та реалізації економічних, соціальних, геополітичних пріоритетів України у статусі морської держави. Задля цього насамперед необхідно здобути та утримувати певні конкуренті переваги. У сегменті морського господарства важливими умовами досягнення конкурентних переваг i забезпечення конкурентоспроможності є стимулювання продуктивності праці, підвищення якості управління, модернізація основних фондів, впровадження інформаційних технологій тощо. У цьому сенсі потрібен одночасний розвиток технологічних та управлінських інновацій, адже технології самі по собі не можуть збільшувати продуктивність, вона зростає лише завдяки відповідним управлінським інноваціям. I вже само управління стає джерелом конкурентоспроможності.

Аналіз останніх досліджень і публікацій. Формування професійних та особистих якостей сучасних менеджерів $\epsilon$ предметом всебічного дослідження науковців різних сфер: економіки, управління, психології. У цьому сенсі слід зупинитися на працях таких науковців, як К.С. Шапошников, О.В. Вітвіцька, О.О. Гетьман, А.В. Плясун, А.М. Ткаченко, І.Н. Андрєєва. Конкурентоспроможність менеджменту як комплексна категорія поки що не досить вивчена і фігурує насамперед у дослідженнях Е.А. Кузнєцова. Отже, $є$ нагальна потреба у розвитку означеного наукового напряму в тому числі й у контексті морегосподарського комплексу України.

Формулювання цілей статті. Метою дослідження є ідентифікація поняття «конкурентоспроможність менеджменту» 3 огляду на специфіку функціонування морегосподарського комплексу, а також формулювання основних якостей сучасних менеджерів, на яких покладається завдання щодо забезпечення означеної конкурентоспроможності.

Виклад основного матеріалу. У сучасному світі за допомогою менеджменту можна забезпечити розвиток соціально-економічної системи в конкурентному середовищі. Але тільки за умови, що технологія, кінцевий продукт, а також система менеджменту є конкурентоспроможними. Тому створення та подальше посилення конкурентних переваг виступають як функції менеджменту на державному, галузевому та локальному рівні, a їх реалізація потребує постійного впровадження інновацій у відповідь на зміни конкурентного середовища.

Таким чином, важливо відзначити, що в сучасних умовах інноваційний шлях розвитку стає найбільш перспективним та конкурентоспроможним для діяльності організації. А система менеджменту повинна не просто володіти професійними знаннями та рішеннями минулих проблем, а й мати управлінський інтелект, який цілком спрямований на майбутній розвиток, що і $є$ головною метою інноваційної діяльності сучасного менеджменту [1, с. 11]. 
Конкурентоспроможність менеджменту ми пропонуємо розглядати як здатність у процесі управлінських дій створювати та підтримувати конкурентні переваги за рахунок процесу професіоналізації управлінської діяльності, впровадження інноваційних форм організації управління, застосування прогресивних систем навчання та мотивації співробітників тощо. В останні роки конкурентоспроможність менеджменту постає самостійним та результативним чинником для підприємств та галузей морегосподарського комплексу в їхньому прагненні до забезпечення стійкої позиції на ринках. Підгрунтям для цього є насамперед конкурентоспроможний управлінський інтелект, а вже потім - асортиментна та цінова політика, технологічний базис тощо.

У цьому контексті величезне значення має комплексне використання принципів конкурентоспроможного менеджменту. Основними 3 них є: створення атмосфери, стимулюючої пошук і освоєння нововведень; націленість інноваційної діяльності на потреби споживача; визначення пріоритетних завдань інноваційної роботи, виходячи з цілей і завдань підприємства; максимальне скорочення строків розроблення та впровадження нововведень на основі одночасного паралельного вирішення інноваційних завдань [2].

Незважаючи на єдність принципів, параметри конкурентоспроможності менеджменту мають певну національну специфіку. Зокрема, менеджмент у Японії особливу увагу приділяє інноваціям в управлінні якістю продукції та робіт, а також заходам щодо саморозвитку персоналу. Саме в Японії вперше була використана система «just-in-time» як засіб оптимізації логістичного циклу. Натомість у США отримала розповсюдження система «участі в прибутках», яка стала не тільки ефективним мотиваційним заходом, але й важелем для покращення результатів підприємницької діяльності.

Першим етапом оцінки конкурентоспроможності управління морегосподарським комплексом України $є$ аналіз його сильних та слабких сторін, а також визначення можливостей та загроз, тобто проведення SWOT-аналізу.
3 погляду перспектив інноваційного розвитку серед суто управлінських питань можна відзначити неузгодженість в управлінні з боку різних органів державної влади, а також створення умов для державно-приватного партнерства, впровадження кластерних моделей, а також налагодження міжнародного співробітництва.

Вітчизняний менеджмент морегосподарського комплексу складно назвати конкурентоспроможним, насамперед внаслідок управлінської неузгодженості. Велика частина підприємств морегосподарського комплексу України підпорядковується Міністерству інфраструктури, а управління іншими напрямами морської діяльності покладено на різні міністерства і відомства. Так, міністерство аграрної політики і продовольства курирує рибопромисловий комплекс. Міністерство економічного розвитку і торгівлі відповідає за суднобудування і судноремонтні підприємства. Міністерство екології та природних ресурсів відповідає 3 наукові дослідження в морській сфері, а також займається природоохоронною діяльністю в Азовському і Чорному морях. Міністерство енергетики та вугільної промисловості розробляє морські шельфи з метою видобутку корисних копалин. Міністерство освіти і науки відповідає за підготовку кадрів для морської діяльності. У прямій компетенції Міністерства регіонального розвитку, будівництва та житлово-комунального господарства перебуває регіональний розвиток приморських регіонів [3, с. 8 ].

На жаль, координація та взаємодія у здійсненні морської діяльності між цими відомствами фактично відсутня. Можливість прискореного відродження такої високорентабельної галузі економіки, як морська, в ситуації відсутності скільки-небудь помітних і, головне, довгострокових державних капіталовкладень $є$ реальною лише за умови організаційних змін та реалізації державою передової регуляторної політики.

Однак ніякі організаційні зміни без відповідного управлінського ресурсу не в змозі забезпечити зміцнення конкурентоспроможності менеджменту. Адже відповідальність, яка покладається на сучасного менеджера, передбачає високий рівень його професійної підготовки і наявність інноваційних механізмів сис-

Таблиця 1

SWOT-аналіз морегосподарського комплексу України

\begin{tabular}{|c|c|}
\hline Сильні сторони & Слабкі сторони \\
\hline $\begin{array}{l}\text { 1. Вигідне географічне розташування } \\
\text { 2. Наявність ресурсної бази } \\
\text { 3. Кадрове забезпечення } \\
\text { 4. Історична спрямованість на морегосподарську діяльність } \\
\text { 5. Значні потужності портового господарства та } \\
\text { суднобудування. }\end{array}$ & $\begin{array}{l}\text { 1. Застарілість основних фондів } \\
\text { 2. Управлінська неузгодженість } \\
\text { 3. Неефективна тарифна політика } \\
\text { 4. Проблеми з доступом до пільгових фінансових ресурсів та } \\
\text { відсутність податкових пільг } \\
\text { 5. Недостатня управлінська кваліфікація } \\
\end{array}$ \\
\hline Можливості & Загрози \\
\hline $\begin{array}{l}\text { 1. Розвиток морського туризму } \\
\text { 2. Впорядкування ситуації із видобутком ресурсів на шельфі } \\
\text { 3.Державно-приватне партнерство у портовому господарстві. } \\
\text { 4. Створення кластерів. } \\
\text { 5. Відновлення флоту } \\
\text { 6. Міжнародне співробітництво в межах Чорноморського регіону. }\end{array}$ & $\begin{array}{l}\text { 1. Продовження агресії з боку Росії та втрата ресурсів } \\
\text { 2. «Відплив умів» та «відплив результатів» } \\
\text { 3. Подальше фізичне та моральне старіння основних фондів }\end{array}$ \\
\hline
\end{tabular}


темного підвищення професійної компетенції протягом практично всієї його управлінської кар'єри. За всієї додаткової важливості емпіричного досвіду управлінських кадрів необхідно відзначити, що в період постіндустріального розвитку суспільства i формування інноваційної економіки його абсолютно не досить. Ефективне управління вимагає від сучасних управлінців лідерських якостей, емоційного інтелекту та креативних здібностей.

У цьому сенсі вони повинні стати «управлінською елітою», тобто сукупністю людей, що володіють цінними для виживання в цьому суспільстві якостями, які щодо населення є дефіцитними. Управлінцями можуть бути не всі люди, адже потрібними якостями володіє найменша частина людської популяції [1, с. 12]. Ядро означеної еліти - це управлінці-лідери, які повинні прагнути до індивідуальних викликів і самовдосконалення, поєднуючи при цьому власний розвиток із розвитком своєї команди.

Для підвищення конкурентоспроможності менеджменту морегосподарського комплексу необхідні не просто досвідчені керівники, а лідери, які ставлять перед собою завдання бути у постійному процесі професійного навчання. Відповідно, єдиний шлях, за яким економічна організація може створювати інноваційне середовище, - це переосмислити старі шляхи діяльності і знайти нові можливості для інноваційного розвитку.

Головним завданням лідера $є$ не пряме використання персоналу як ресурсу чи капіталу, а розвиток людського потенціалу. Така трансформація засвідчує принципову зміну ролі людського чинника в організаційному розвитку, оскільки під час адміністрування люди є лише інструментом використання матеріальних ресурсів, під час менеджменту персонал уже сам по собі стає ресурсом, і тільки лідерство підкреслює цінність розвитку людського потенціалу в контексті розвитку організації.

3 огляду на це У. Бенніс виділяе такі типи лідерів: представник - це людина, яка відповідає за свої рішення та вчинки перед вищим керівництвом; виконавець (особистість) - це конкретна людина, яка $є$ керівником, тобто лідером на певний час; підлідер це людина, яка має певну незалежну владу, але вона $\epsilon$ представником групи та відповідальна перед цією групою; дійсний лідер - це людина, рішення якої матимуть певні наслідки у майбутньому, яка організує та керує роботою [4, с. 50].

На відміну від адміністрування та менеджменту, лідерство несумісне з примусом, воно можливе лише за умов взаємної довіри та поваги. Завдяки цьому результатом лідерських відносин $є$ партнерські стосунки, плідна співпраця, добровільне об'єднання зусиль для досягнення спільно усвідомленого результату, ефективне функціонування управлінських команд тощо.

Поряд із лідерством важливим є й професійний розвиток, який слід розуміти як цілеспрямований та систематичний вплив на працівників шляхом професійного навчання впродовж їхньої трудової діяльності
3 метою досягнення високої ефективності виробництва, підвищення конкурентоспроможності персоналу на ринку праці, забезпечення виконання працівниками нових, більш складних завдань на основі максимально можливого використання їхніх здібностей [5, с. 195].

Слід зауважити, що професійний розвиток управлінців моргосподарського комплексу повинен відбуватися за кількома напрямами: особистий розвиток у сфері управління, посилення компетенцій у сфері основної діяльності (робота портового господарства, підприємства суднобудування, морського транспорту), а також освоєння допоміжних навичок у сфері маркетингу, аналізу бізнес-процесів тощо.

У цьому сенсі розвиток управлінського персоналу виступає каталізатором безперервного організаційного та особистісного росту шляхом удосконалення професійних компетенцій, розширення обсягу знань, підвищення компетентності, здатності до навчання, інтересу до змісту праці. Його основна мета полягає у збільшенні «віддачі» кожного працівника, структурного підрозділу та організації загалом за рахунок «підкріпленої і вмотивованої» лояльності працівників [6, с. 99].

Проте професійний розвиток без підтримки відповідного емоційного стану може призвести до «вигорання». Отже, в останні роки все більшої актуальності для управлінців набуває емоційний інтелект і пов 'язані 3 ним емоційна культура та емоційна компетентність особистості. Під емоційним інтелектом розуміють сукупність ментальних здібностей до розуміння власних емоцій і емоцій інших людей, а також до керування емоційною сферою [7, с. 87]. С 5 обов'язкових складників емоційного інтелекту, які вкрай необхідні сучасному менеджеру: самоусвідомлення, самоконтроль, навички спілкування, емпатія та самомотивація.

3 емоційним інтелектом тісно пов'язана й креативність. 3 погляду економіки та менеджменту креативність виступає як здатність створювати і знаходити нові ідеї, відхиляючись від прийнятих схем мислення, успішно вирішувати завдання, які постають перед підприємством, нестандартним чином [8, с. 5]. Креативні якості конкурентоспроможного менеджменту реалізуються насамперед у певному типі мислення, властивому управлінцям економіки знань. Такі управлінці завжди виявляють інтерес до саморозвитку, характеризуються відкритістю, незалежністю, наполегливістю, готовністю до створення принципово нових ідей, позбавлених традиційного мислення. Високий інтелектуальний потенціал у них перебуває у єдності з інноваційною лояльністю. Модель управління, на чолі якої стоїть такий менеджер, набуває ефекту синергії в інноваційному процесі, оскільки інноваційні технології не тільки тиражуються, але й розгортаються завдяки механізму креативного коучингу і партнерських відносин [9, с. 127].

Креативність як сукупність творчих здібностей індивіда є природним талантом. Проте є декілька дієвих способів іiі стимулювання: правильний розподіл робочих завдань, надання працівникам свободи вибору засобів для досягнення цілей, обгрунтований розпо- 
діл часу і коштів для розв'язання завдання, створення робочої групи, члени якої готові до взаємодії й вирізняються глибиною неординарного мислення і поглядів, заохочення працівників, організаційна підтримка [10].

Висновки. У сучасному світі основними джерелами конкурентоспроможного менеджменту постають професіоналізація управлінської діяльності, впровадження інноваційних форм організації управління, застосування прогресивних систем навчання та мотивації співробітників. Усе це відбувається на тлі підвищення значення процесів інформатизації в управлінні.
У найближчому майбутньому в усіх сферах господарської діяльності, в тому числі й у морських галузях, спостерігатиметься попит на управлінців нового покоління, здатних стати повноцінними представниками управлінської еліти. Тому підготовка менеджерів не тільки належного професійного рівня, які намагаються підвищувати його на протязі всієї своєї кар'єри, але й здатних до лідерства, з відповідним рівнем креативності та емоційного інтелекту, повинна стати основним завданням у контексті забезпечення конкурентоспроможності менеджменту вітчизняного морегосподарського комплексу.

\section{Список літератури:}

1. Кузнєцов Е.А. Конкурентноспроможна система менеджменту як умова соціально-економічного суверенітету держави. Ринкова економіка: сучасна теорія і практика управління. 2018. Т. 18. Вип. 1(41). С. 9-24.

2. Продіус О.І. Проблеми та перспективи впровадження інноваційних проектів на вітчизняних підприємствах. Науковий вісник Херсонського державного університету. Сер. : Економічні науки. 2016. Вип. 19(2). С. 91-95.

3. Гайду О.В. Державні пріоритети розвитку морегосподарського комплексу України: науковий огляд наявних і прихованих можливостей. Вісник Національного університету ичивільного захисту України. Серія : Державне управління. 2016. Вип. 2. С. 1-12.

4. Bennis Warren. Reinventing Leadership. Cambridge, 1992. P. 46-60.

5. Ткаченко А.М., Ткаченко К.А. Професійний розвиток персоналу - нагальне завдання сьогодення. Економічний вісник Донбасу. 2014. № 1. С. 194-197.

6. Гетьман О.О., Плясун А.В. Розвиток персоналу в забезпеченні безпеки ринку праці. Економічні науки. Вісник Запорізького національного університету. 2016. № 1(29). С. 97-105.

7. Андреева И.Н. О становлении понятия «эмоциональный интеллект». Вопросы психологии. 2008. № 5. С. 83-95.

8. Журавлев В.А. Креативное мышление, креативный менеджмент и инновационное развитие общества. Креативная экономика. 2008. № 4. С. 3-8.

9. Шапошников К.С. Інноваційна культура як провідний чинник розвитку інноваційних процесів у національній економіці. Науковий вісник Херсонського державного університету. 2013. Випуск 3. С. 126-129.

10. Вітвіцька O.В., Підвальна О.Г. Креативний менеджмент в діяльності підприємства URL: http://www.rusnauka. com/34-NIEK-2010/Economics/ (дата звернення: 29.07.2019)

\section{References:}

1. Kuznetsov E.A. (2018). Konkurentnospromozhna systema menedzhmentu jak umova socialjno-ekonomichnogho suverenitetu derzhavy [Competitive management system as a condition of socio-economic sovereignty of the state] Rynkova ekonomika: suchasna teorija i praktyka upravlinnja [Market Economics: Modern Management Theory and Practice]. 1, 9-24. (in Ukrainian)

2. Prodius O.I. Problemy ta perspektyvy vprovadzhennja innovacijnykh proektiv na vitchyznjanykh pidpryjemstvakh [Problems and prospects of implementation of innovative projects at domestic enterprises]. Scientific Bulletin of Kherson State University. Avg. : Economic Sciences, no. 19. pp 91-95.

3. Gaidu O.V. (2016). Derzhavni priorytety rozvytku moreghospodarsjkogho kompleksu Ukrajiny: naukovyj oghljad najavnykh i prykhovanykh mozhlyvostej [State priorities for the development of Ukraine's marine economic complex: a scientific review of available and hidden opportunities]. Visnyk Nacionaljnogho universytetu cyviljnogho zakhystu Ukrajiny. Serija : Derzhavne upravlinnja [Bulletin of the National University of Civil Protection of Ukraine. Series: Public Administration]. 2, 1-12, (in Ukrainian)

4. Bennis W. Reinventing Leadership. Cambridge, 1992. P. 46-60. (in English)

5. Tkachenko A.M., Tkachenko K.A. (2014). Profesijnyj rozvytok personalu - naghaljne zavdannja sjoghodennja [Professional development of the staff is an urgent task today]. Ekonomichnyj visnyk Donbasu [Economic Bulletin of Donbass]. 1, 194-197. (in Ukrainian)

6. Getman O.O., Plyasun A.V. (2016). Rozvytok personalu v zabezpechenni bezpeky rynku praci [Staff development in labor market security]. Ekonomichni nauky: Visnyk Zaporizjkogho nacionaljnogho universytetu [Economics: Bulletin of Zaporizhzhya National University]. 1, 97-105. (in Ukrainian)

7. Andreeva I.N. (2008). O stanovlenii ponyatiya «emotsional'nyy intellekt» [On the formation of the concept of "emotional intelligence"]. Voprosy psikhologii [Psychology Issues]. 5, 83-85. (in Russian)

8. Zhuravlev V.A. (2008). Kreativnoe myshlenie, kreativnyy menedzhment i innovatsionnoe razvitie obshchestva. [Creative thinking, creative management and innovative development of society]. Kreativnaya ekonomika [Creative economy]. 4, 3-8. (in Russian)

9. Shaposhnikov K.S. (2013). Innovacijna kuljtura jak providnyj chynnyk rozvytku innovacijnykh procesiv u nacionaljnij ekonomici [Innovation culture as a leading factor in the development of innovation processes in the national economy]. Naukovyj visnyk Khersonsjkogho derzhavnogho universytetu [Scientific Bulletin of Kherson State University]. 3, 126-129. (in Ukrainian)

10. Vitvitska O.V., Pidvalna O.G. Kreatyvnyj menedzhment v dijaljnosti pidpryjemstva. [Creative management in the activity of the enterprise]. URL: http://www.rusnauka.com/34-NIEK-2010/Economics/ (accessed 29 July 2019). (in Ukrainian) 


\section{КОНКУРЕНТОСПОСОБНОСТЬ МЕНЕДЖМЕНТА МОРЕХОЗЯЙСТВЕННОГО КОМПЛЕКСА УКРАИНЫ}

В статье рассматриваются теоретические вопросы касаемо дефиниции категории «конкурентоспособность менеджмента». Сформулированы основные принципы конкурентоспособного управления. $B$ контексте выявления управленческих резервов проведен SWOT-анализ морехозяйственного комплекса. Среди присущих ему управленческих проблем выделена управленческая несогласованность и отсутствие надлежсащего профессионального уровня менеджмента. Определено, что обеспечение конкурентоспособности менеджмента требует от управленческого персонала не только профессиональных навыков, но и лидерских качеств, эмоционального интеллекта и креативных способностей. Доказана необходимость системного повышения квалификации управленческими кадрами на протяжении всей карьеры. Сформированы предложения по формированию основных характеристик менеджеров нового поколения, способных обеспечить конкурентоспособность управления морехозяйственным комплексом в будущем.

Ключевые слова: морехозяйственный комплекс, инновация, конкурентоспособность менеджмента, лидерство, креативность, эмоциональный интеллект.

\section{COMPETITIVENESS MANAGEMENT OF THE MARITIME COMPLEX IN UKRAINE}

The article deals with theoretical issues regarding the definition of the category "competitiveness of management". It is determined that in modern conditions the innovative way of development becomes the most promising or competitive for the activity of the organization. And the management system must have not only a professional knowledge of solving past problems, but also have a management intellect that is fully aimed at future development, which, in general, is the main goal of innovative management of modern management. The basic principles of competitive management are formulated. In the context of determining reserves for management optimization, a SWOT analysis of the Ukrainian maritime complex was conducted and identified its major management issues. Among the latter is administrative inconsistency and lack of proper professional level of managers. The appropriateness of using the term "managerial elite" for the population of people with deficiency-deficient values in this society has been proved. Thus, not all people may be managers, that is, the smallest part of the human population possesses the nourishing qualities. For set themselves the task of being in a continuous vocational training process are needed to improve management competitiveness. Accordingly, the only way for an economic organization to create an innovative environment is to rethink old ways of doing business and find new opportunities for innovative development. It is determined that ensuring competitiveness of management requires from management personnel not only professional skills and experience, but also leadership qualities, emotional intelligence and creative abilities. Of particular importance is leadership itself, which is incompatible with coercion and possible only under conditions of mutual trust and respect. Due to this, the results of leadership relations are partnerships, fruitful cooperation, voluntary joint efforts to achieve a jointly conscious result, the effective functioning of management teams and so on. The necessity of systematic increase of managers their professional competence throughout the car 'premieres . Proposals are made on the formation of the main characteristics of the new generation of managers, which should ensure the competitiveness of management.

Key words: sea economic complex, innovation, competitiveness of management leadership, creativity, emotional intelligence. 